\title{
Evolution of Tn21-related Transposons: Isolation of Tn2425, which Harbours IS161
}

\author{
By JOACHIM F. MEYER, BERTHOLD A. NIES, JOHANNES KRATZ AND \\ BER ND WIEDEMAN N* \\ Institut für Medizinische Mikrobiologie und Immunologie der Universität Bonn, \\ An der Immenburg 4, 5300 Bonn, FRG
}

(Received 21 August 1984; revised 19 November 1984)

The isolation of two multi-resistance transposons, $\operatorname{Tn} 2425$ and $\operatorname{Tn} 1831$, and their relation to $\mathrm{Tn} 21$ and $\mathrm{Tn} 2424$, is described. A $1.7 \mathrm{~kb}$ segment present in $\mathrm{Tn} 2424$ and $\mathrm{Tn} 2425$ was identified as an IS element by rec-independent transposition, resulting in a cointegrate structure that carries two direct repeated copies of the IS element. By the isolation of this IS element we demonstrated that transposition is one mechanism leading to sequence variations in Tn21-like structures, especially in the region between the mer operon and the sul gene.

\section{INTRODUCTION}

The transposon $\operatorname{Tn} 21$ has been shown to harbour the genes encoding resistance towards mercuric chloride (mer gene), sulphonamides (sul gene) and streptomycin/spectinomycin (aadA gene) as well as the transposition functions $\operatorname{tnp} R$ (resolvase) and $\operatorname{tnp} A$ (transposase) (De la Cruz \& Grinsted, 1982).

Recently, we described the isolation of the multi-resistance transposons Tn2424 (Meyer et al., 1983 ) and $\operatorname{Tn} 2411$ (Kratz et al., 1983a). Tn2424 mediated resistance to mercuric chloride $\left(\mathrm{Hg}^{\mathrm{R}}\right)$, sulphonamides $\left(\mathrm{Su}^{\mathrm{R}}\right)$, streptomycin/spectinomycin $\left(\mathrm{Spec}^{\mathrm{R}}\right)$ [AAD- $\left.\left(3^{\prime \prime}\right)\right]$, chloramphenicol $\left(\mathrm{Cm}^{\mathrm{R}}\right)$ and amikacin $\left(\mathrm{Ami}^{\mathrm{R}}\right)$ [AAC- $\left.\left(6^{\prime}\right)\right]$, and included the total sequence of $\mathrm{Tn} 2 l$ and two additional DNA segments of 1.7 and $4.0 \mathrm{~kb}$. The latter fragment encoded resistance to amikacin (aacA gene) and chloramphenicol ( $\mathrm{clm}$ gene), whereas the smaller one lacked detectable functions (Meyer et al., 1983). Tn2411 was completely included in Tn21 but lacked a $1.45 \mathrm{~kb}$ segment (Kratz et al., 1983a).

Tanaka et al. (1983) presented a model of the evolution of Tn21-related multi-resistance transposons based on an ancestral mercury transposon Tn2613. Despite their structural relationship, these elements differed in several insertions within the region between the mer operon and the sul gene.

In order to investigate these sequence variations, we isolated and compared additional $\operatorname{Tn} 21$ related elements. Because of their length and the lack of detectable functions some of the inserted fragments are assumed to represent IS elements.

\section{METHODS}

The plasmids and bacterial strains used are listed in Table 1. All methods, such as DNA preparation, the transformation procedure, electron microscopy, DNA digestions, and cloning experiments, have been described before (Meyer et al., 1983).

Resistances towards different drugs are abbreviated as follows: $\mathrm{Hg}^{\mathrm{R}}$ (mercuric chloride), $\mathrm{Su}^{\mathrm{R}}$ (sulphonamides), $\mathrm{Sm}^{\mathrm{R}}$ (streptomycin), $\mathrm{Spec}^{\mathrm{R}}$ (spectinomycin), $\mathrm{Cm}^{\mathrm{R}}$ (chloramphenicol), $\mathrm{Tc}^{\mathrm{R}}$ (tetracycline), $\mathrm{Ap}^{\mathrm{R}}$ (ampicillin), $\mathrm{Km}^{\mathrm{R}}$ (kanamycin), Ami ${ }^{R}$ (amikacin) and $\mathrm{Tp}^{R}$ (trimethoprim).

The designation of genotypes follows the nomenclature of Bachmann (1983). 
Table 1. Bacterial strains, plasmids and transposons

Strains

Escherichia coli JC2926

E. coli SK 1592

Plasmids

pHSI

pBP81

pBP812

pBP8124

pNO1523

pMH2

R702

pUB307

R751

Transposons

pACYC184:: Tn 21

pBR322: : $\operatorname{Tn} 2424$

pBR322:: $\operatorname{Tn} 2411$

pNO1523:: $\operatorname{Tn} 2425$

pNO1523:: $\operatorname{Tn} 1831$
Relevant characteristics*

Reference

rpsL recA thi thr arg his lac

gal thi ton sbcB15 hsr4 $\mathrm{rec}^{+}$

$T c^{R}$. Temperature sensitive in replication

$\mathrm{Ap}^{\mathrm{R}} \mathrm{Hg}^{\mathrm{R}}$. Ligated SalI fragment of pBR322:: $\operatorname{Tn} 2424$

$\mathrm{Ap}^{R} \mathrm{Hg}^{\mathrm{R}} \mathrm{Tc}^{\mathrm{R}}$. Cointegrate between $\mathrm{pBP} 81$ and $\mathrm{pHSl}$

$\mathrm{Tc}^{\mathrm{R}}$. pHSI ::ISI6l

$\mathrm{Ap}^{\mathrm{R}}$. pBR322 derivative harbouring a cloned $r p s L(\operatorname{str} A)$ gene

$\mathrm{Tc}^{\mathrm{R}} \mathrm{Cm}^{\mathrm{R}} \mathrm{Hg}^{\mathrm{R}} \mathrm{Su}^{\mathrm{R}} \mathrm{Sm}^{\mathrm{R}} / \mathrm{Spec}^{\mathrm{R}} \operatorname{tra}^{+}$. One part of the $\mathrm{R}$ plasmid R5

$\mathrm{Km}^{\mathrm{R}} \mathrm{Tc}^{\mathrm{R}} \mathrm{Su}^{\mathrm{R}} \mathrm{Sm}^{\mathrm{R}} / \mathrm{Spec}^{\mathrm{R}} \mathrm{Hg}^{\mathrm{R}} \operatorname{tra}^{+}$

$\mathrm{Km}^{\mathrm{R}} \mathrm{Tc}^{\mathrm{R}} \operatorname{tra}^{+}$

$\mathrm{Tp}^{\mathrm{R}}$ tra $^{+}$

$\mathrm{Cm}^{R} \mathrm{Hg}^{\mathrm{R}} \mathrm{Su}^{R} \mathrm{Sm}^{\mathrm{R}} / \mathrm{Spec}^{\mathrm{R}}$

$\mathrm{Ap}^{R} \mathrm{Hg}^{\mathrm{R}} \mathrm{Su}^{\mathrm{R}} \mathrm{Sm}^{\mathrm{R}} / \mathrm{Spec}^{\mathrm{R}} \mathrm{Cm}^{\mathrm{R}} \mathrm{Ami} \mathrm{i}^{\mathrm{R}}$

$\mathrm{Ap}^{R} \mathrm{Tc}^{R} \mathrm{Su}^{R} \mathrm{Sm}^{R} / \mathrm{Spec}^{R}$

$\mathrm{Ap}^{R} \mathrm{Hg}^{R} \mathrm{Su}^{R} \mathrm{Sm}^{R} / \mathrm{Spec}^{R}$

$\mathrm{Ap}^{\mathrm{R}} \mathrm{Hg}^{\mathrm{R}} \mathrm{Su}^{\mathrm{R}} \mathrm{Sm}^{\mathrm{R}} / \mathrm{Spec}^{\mathrm{R}}$

* See Methods for abbreviations.
Bachmann (1972)

Kushner (1978)

Hashimoto \& Sekiguchi (1976)

This paper

This paper

This paper

Dean (1981)

Haas \& Davies (1980)

Villarroel et al. (1983)

Bennett et al. (1975)

Meyer \& Shapiro (1980)

This paper

Meyer et al. (1983)

Kratz et al. (1983a)

This paper

This paper

\section{RESULTS}

Isolation and characterization of Tn2425 and Tn1831

The IncPl plasmid R702 harbours a transposon of about $15.5 \mathrm{~kb}$, designated $\operatorname{Tn} 1831$ (Villarroel et al., 1983). The IncFII plasmid pMH2 has been demonstrated to share extensive homology to R100, from which Tn21 originated (Haas \& Davies, 1980). Therefore, we tested plasmids $\mathrm{R} 702$ and $\mathrm{pMH} 2$ for transposition of $\mathrm{Tn} 21$-related elements.

Transposition experiments were done in Escherichia coli JC2926 (recA), with pNO1523 as the recipient plasmid. This replicon consists of pBR322 carrying a cloned $r p s L$ gene, the chromosomal gene encoding the ribosomal S12 protein. This rps $L$ gene is dominant to its chromosomal mutation in streptomycin resistant mutants and leads to phenotypic streptomycin sensitivity. Thus, the insertion of a transposable element into the rpsL region of pNO1523 is detectable by selection for the activation of the chromosomal streptomycin resistance.

DNA of $E$. coli JC2926 harbouring pMH2/pNO1523 or R702/pNO1523 was used to transform $E$. coli $\mathrm{JC} 2926$ with selection for ampicillin and spectinomycin resistance, and for high levels of streptomycin resistance $\left(1 \mathrm{mg} \mathrm{m}^{-1}\right)$. The resulting transformants were replicated for tetracycline, chloramphenicol and kanamycin sensitivity.

Representative clones of pNO1523:: $\operatorname{Tn} 1831$ and pNO1523:: $\operatorname{Tn} 2425$ (Tn21-related transposons from pMH2), which occurred with frequencies between $10^{-5}$ to $10^{-6}$, and $\mathrm{pA}-\mathrm{CYC}$ $184:: \operatorname{Tn} 21$, pBR322::Tn2424 and pBR322::Tn2411 were subjected to restriction and heteroduplex analysis (Fig. 1). Tn21 was completely included in Tn2425, which was itself homologous to Tn2424 except that it lacked the insertion of the amikacin and chloramphenicol resistance genes (Fig. 1). Tn2425 included all the restriction sites present in Tn21, and, in addition, an insertion of about $1.7 \mathrm{~kb}$ between the mer and the sul genes (designated insertion loop 3). Insertion loop 3 of $\operatorname{Tn} 2425$ corresponded to the $1.7 \mathrm{~kb}$ fragment detected in heteroduplexes between Tn2424 and Tn21 (Meyer et al., 1983). Tn1831 differed from Tn21 in the lack of a $2.8 \mathrm{~kb}$ fragment (loop 2 in Fig. 1) at a distance of about $4.3 \mathrm{~kb}$ from the left inverted repeat. Furthermore, one BamHI restriction site present in all the Tn2l-like elements was not detectable in $\operatorname{Tn} 1831$.

Additional transposition experiments revealed that both $\operatorname{Tn} 1831$ and $\operatorname{Tn} 2425$ were transferable to other plasmids, such as pUB307 or R751. 

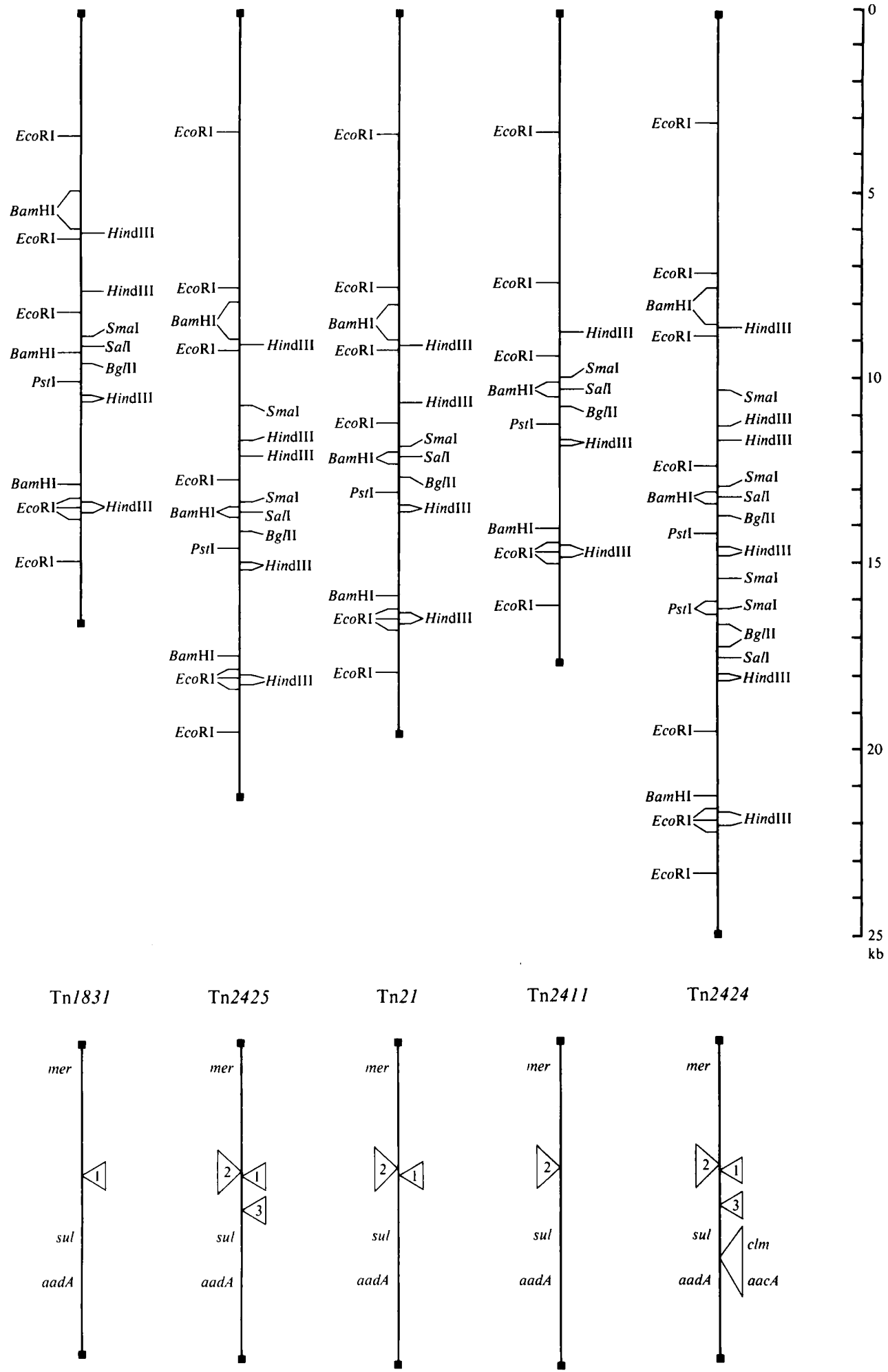

Fig. 1. Restriction maps and schematic structures of several Tn2l-related elements. The maps of Tn2424, Tn2l and Tn2411 are taken from Meyer et al. (1983) and Kratz et al. (1983a). The closed boxes at the ends of the structures indicate the inverted repeats. The insertion loops (1-3) correspond to the insertions detected in different heteroduplexes. Their lengths were measured to be $1.45 \mathrm{~kb}$ (loop 1), $2.8 \mathrm{~kb}$ (loop 2) and $1.7 \mathrm{~kb}$ (loop 3). All transposons have been reduced to their common backbone structure. 


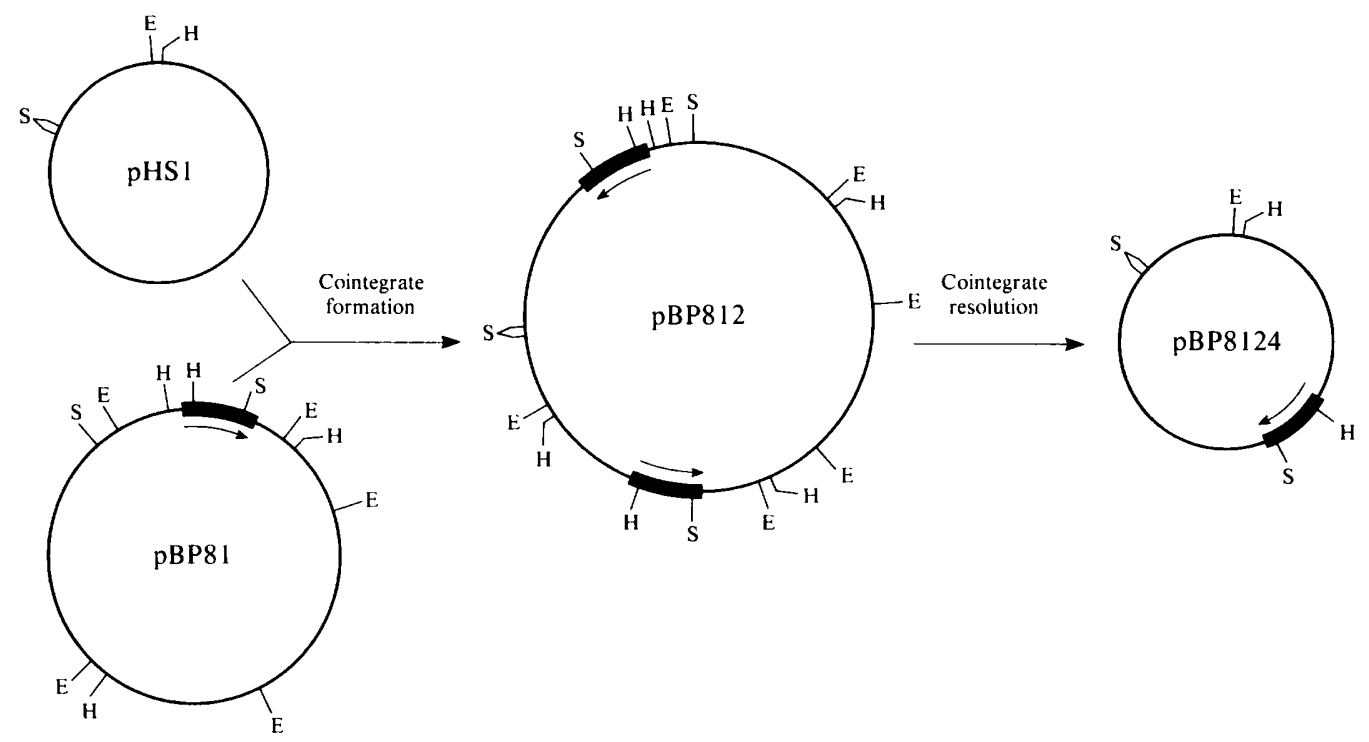

Fig. 2. Isolation procedure of IS 161 . E. coli JC2926 harbouring pHS1 and pBP81 was selected at $42{ }^{\circ} \mathrm{C}$ for ampicillin and tetracycline resistance. The cointegrate structure pBP812 was resolved either in rec $A$ or $\mathrm{rec}^{+} E$. coli strains by recombination involving the two direct repeats of IS 161 . (The arrows indicate the orientation of the IS elements in the plasmids.) The letters correspond to the following restriction sites: H, HindIII; S, SmaI; E, EcoRI.

\section{Cointegrate formation after transposition of insertion loop 3}

The ease of transposition of the different insertion loops present in the region between the mer operon and the sul gene was investigated using the left part of $\operatorname{Tn} 2424$, as this included the corresponding sequence, and all three insertion loops, of $\operatorname{Tn} 2425$.

The plasmid pBR322::Tn2424 was digested with Sall and the resulting fragments were ligated with T4 DNA ligase. After transformation we screened for $\mathrm{Ap}^{R} \mathrm{Hg}^{R} \mathrm{Cm}^{\mathrm{S}} \mathrm{Spec}^{\mathrm{S}} \mathrm{Tc}^{\mathrm{S}}$ colonies. One clone, carrying a self ligated $S a l l$ fragment, was designated pBP81. This plasmid consisted of one part of pBR322 and the left side of Tn2424, including the mer genes and the three insertion loops.

As has been depicted in several models for transposition (Muster \& Shapiro, 1981; Galas and Chandler, 1981), the transposition of an IS element results in a cointegrate structure between the donor and the recipient replicons. $\mathrm{pHS} 1$ ( $\mathrm{Tc}^{\mathrm{R}}$ and temperature sensitive in replication) was used as the recipient plasmid during cointegrate formation with the donor pBP81 (Fig. 2). E. coli JC2926 (recA), transformed with both plasmids, was grown at $42^{\circ} \mathrm{C}$ selecting for ampicillin and tetracycline resistance. As pHS1 is unable to replicate at $42{ }^{\circ} \mathrm{C}$, only cointegrates formed between pHS1 and pBP81 were able to mediate this phenotype at this temperature. Corresponding clones were detected at a frequency of about $10^{-7}$ (in relation to $\mathrm{Ap}^{\mathrm{R}} \mathrm{Tc}^{\mathrm{R}}$ colonies at $37^{\circ} \mathrm{C}$ ) and purified at $42^{\circ} \mathrm{C}$ with selection for $\mathrm{Ap}^{\mathrm{R}} \mathrm{Tc}^{\mathrm{R}}$ colonies. The DNA of six clones was used to transform E. coli JC2926 and the plasmids of the resulting transformants were analysed by endonuclease digestion.

Of the six $\mathrm{pHS1} / \mathrm{pBP} 81$ cointegrates that were analysed, one was probably due to the transposition of IS102 (Machida et al., 1982) from pHS1, while the other five were formed via insertion loop 3, now designated IS161 (in agreement with the Plasmid Reference Center, Stanford University, Calif., USA). Restriction patterns revealed that IS 161 had transposed into different regions of pHS1 in each cointegrate.

One representative IS161-mediated cointegrate, pBP812, was used for further experiments. The restriction profile of this plasmid in relation to pHS1 and pBP81 is shown in Figs 2 and 3. IS161 is located on the third EcoRI fragment of pBP81 and carries a SmaI restriction site. From the transposition models mentioned above, one would expect a cointegrate structure with 

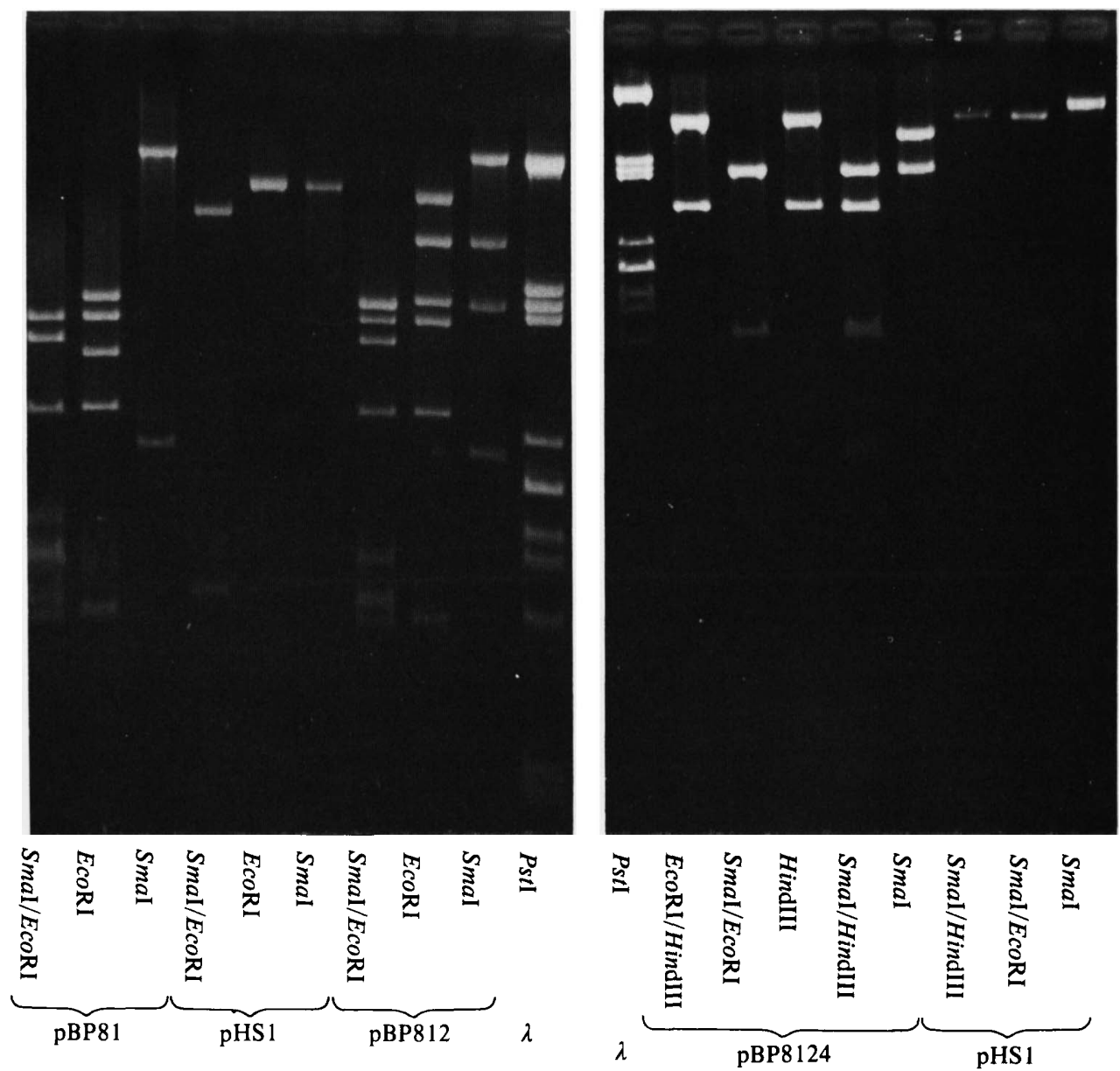

Fig. 4.

Fig. 3.

Fig. 3. Restriction analysis of pBP81, pHS1 and pBP812, a cointegrate formed between pHS1 and pBP81 via IS 161 . The lane representing SmaI digested pBP812 apparently indicates the duplication of IS 161 , which carries one restriction site for SmaI. In pBP812 the SmaI fragments of pBP81 (donor plasmid) remained unchanged, whereas the $S m a I$ fragment of pHS1 $(9 \cdot 2 \mathrm{~kb})$ forms two distinct fragments, with sizes of about 4.4 and $6.5 \mathrm{~kb}$, due to the insertion of IS161. The small SmaI restriction fragment of pHS1 $(0.2 \mathrm{~kb})$ is not visible in this gel $(1 \%$ agarose).

Fig. 4. Restriction analysis of pBP8124 (pHS1 : :IS16I) and pHS1. SmaI/EcoRI digestion of pBP8124 generates two fragments of about $4.6 \mathrm{~kb}$ that are unresolved owing to their similar size. SmaI/HindIII digestion results in a fragment that corresponds to the internal part of IS161.

duplicated IS elements (each carrying a $S m a I$ restriction site) that flank the ends of the donor plasmid (pBP81) as direct repeated copies (Fig. 2). The results shown in Fig. 3 support this assumption, as one additional SmaI restriction site was detected in pBP812 and both SmaI fragments of the donor plasmid remained unchanged.

\section{Cointegrate resolution in $\mathrm{rec}^{+}$and recA $E$. coli strains}

The cointegrate plasmid pBP812 was used to transform E. coli SK1592 $\left(\right.$ rec $\left.^{+}\right)$. As the two copies of the IS element are directly repeated, the cointegrate can undergo homologous recombination and thus be resolved into the original donor and recipient plasmids, each carrying one copy of the IS element. The DNA of a transformant clone E. coli SK1592(pBP812) was prepared, and was used to transform $E$. coli JC2926. Transformants were selected for 


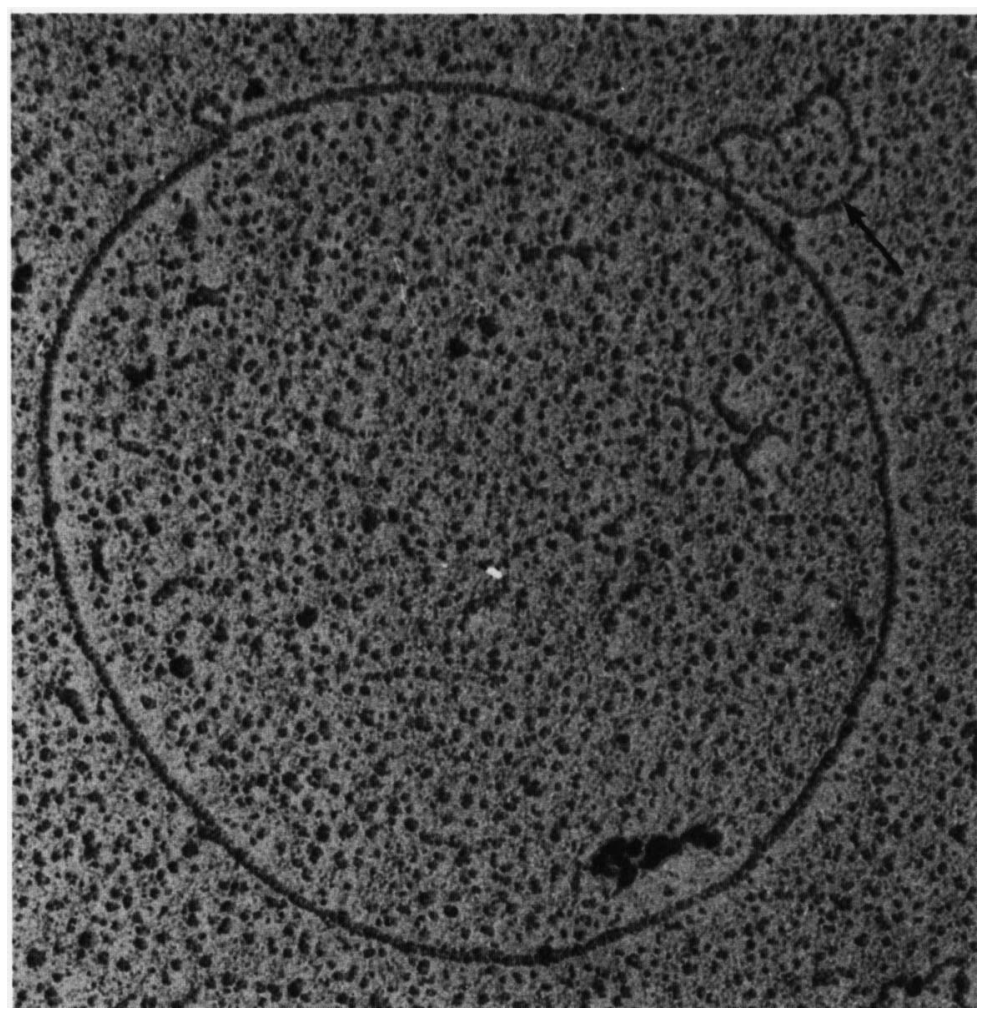

Fig. 5. Heteroduplex formed between pHSI and pBP8124 (pHS1 ::IS/6I). Measurement of different structures resulted in a length of $1.7 \mathrm{~kb}$ for 1 S 161 (arrowed) using single stranded $\phi \times 174$ DNA $(5375 \mathrm{~kb})$ as an internal length standard. Magnification $\times 67000$.

tetracycline resistance and replicated for ampicillin sensitivity (loss of pBP81). Four clones out of 500 showed this phenotype.

Restriction data (Figs 2 and 4) and electron microscope heteroduplex analysis (Fig. 5) revealed that these four clones carried pHS1::IS161 (pBP8124). Furthermore, the restriction data indicated the location and orientation of IS161. The SmaI and HindIII sites internal to IS 161 are separated by a fragment of about $1 \mathrm{~kb}$ (Fig. 4, lane 5). No restriction sites for $B g / \mathrm{II}$, EcoRI, PstI, BamHI, SalI or PvuII were detectable in IS161. Length measurements of heteroduplexes ( 53 molecules) formed between pHS1 and pBP8124 verified the size of IS161 to be $1.7 \mathrm{~kb}$.

Resolution of the cointegrate pBP812 in a $r e c A$ background was determined by isolation of the DNA from E. coli JC2926 followed by Pst I digestion and transformation with selection for $\mathrm{Tc}^{\mathrm{R}}$ transformants. As pHS1 and the IS element contain no Pst I restriction site, only pBP81 and the cointegrate $\mathrm{pBP} 812$ were cleaved, whereas $\mathrm{pHS} 1::$ IS161 remained intact. Transformation with selection for tetracycline resistance resulted in a frequency of about $10^{-4}\left(\mathrm{Tc}^{\mathrm{R}}\right.$ transformants obtained with Pst I-digested versus undigested $\mathrm{pBP} 812$ ). The resulting clones harboured a plasmid, indistinguishable from $\mathrm{pBP} 8124$ from the $\mathrm{rec}^{+}$strain.

In additional transposition experiments, using pBP8124 as donor plasmid, we isolated cointegrates formed with pBP84-1 or R751.

\section{DISCUSSION}

Previously described Tn21-related transposable elements (Meyer et al., 1983; Kratz et al., $1983 a, b$; Tanaka et al., 1983) differed (i) in the region adjacent to the aadA gene, due to insertions or substitutions of different resistance genes, and (ii) in several short sequences in the 


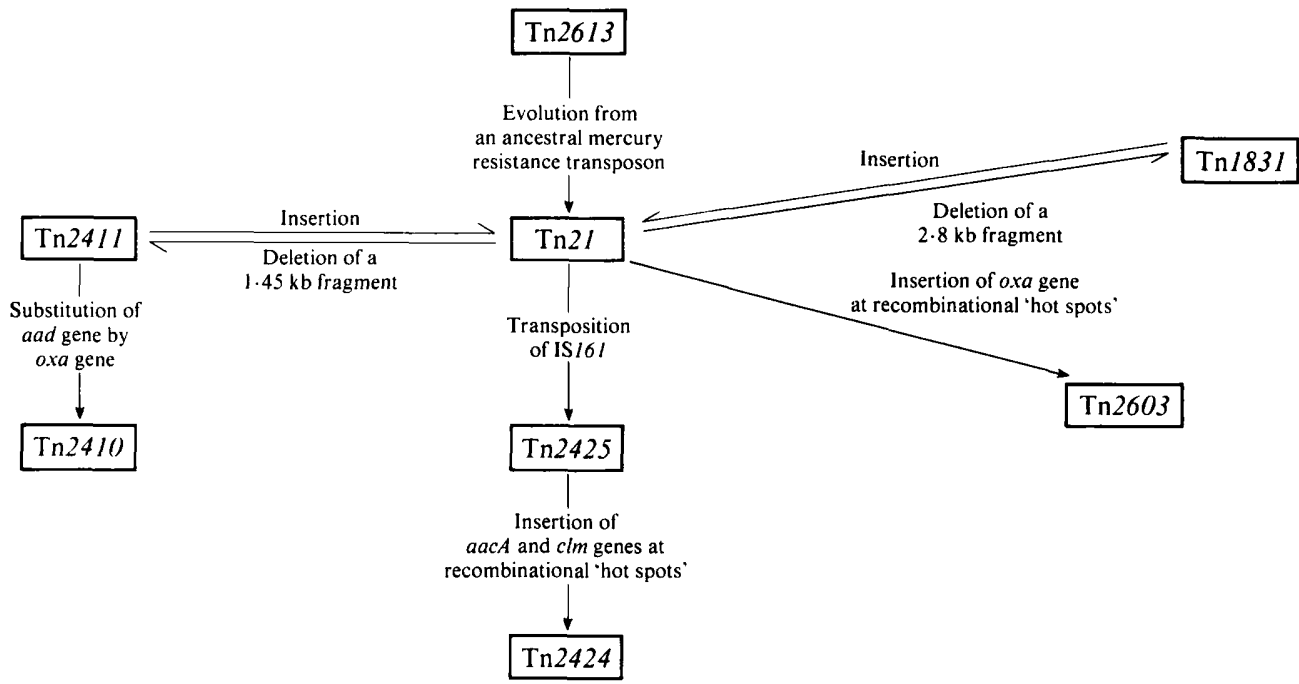

Fig. 6. Evolutionary relationships of $\operatorname{Tn} 21$-related transposons.

region between the mer and the sul genes. The latter fact was supported by the isolation of $\operatorname{Tn} 1831$ and $\operatorname{Tn} 2425$; the former has one less insertion loop, and the latter one more insertion loop, than $\operatorname{Tn} 21$.

With the isolation of IS 161 , we have defined one of the sequences that distinguishes $\operatorname{Tn} 21$ and $\operatorname{Tn} 2424$, which is also the sequence that distinguishes $\operatorname{Tn} 21$ and $\operatorname{Tn} 2425$, and have shown it to behave as an IS element. Comparison of the length and the restriction pattern revealed that IS 161 is distinct from IS $1-5$, IS 8 , IS 10 , IS 15 , IS50, IS 51 , IS 102 or IS 903 (Comai \& Kosuge, 1983; Depicker et al., 1980; Kleckner, 1981; Labigne-Roussel \& Courvalin, 1983). Despite the fact that we have not demonstrated the transposition of other insertion-like sequences from $\operatorname{Tn} 21$ related structures, it seems reasonable to suggest that the transposition of IS elements into the left part of $\mathrm{Tn} 21$-like elements is a likely cause of sequence variations in this group of related transposons.

Finally, summarizing all the data on the numerous $\operatorname{Tn} 21$-like elements, Fig. 6 represents a reasonable scheme of several mechanisms involved in the evolutionary relation of these structures. From previous work of Tanaka et al. (1983), Tn2l seems to have evolved from an ancestral mercury-resistance transposon such as Tn2613. Transposition of IS161 into Tn21 resulted in the structure of $\mathrm{Tn} 2425$. By the insertion of the genes encoding chloramphenicol and amikacin resistance at the predicted recombiantional 'hot spots' adjacent to the aadA gene (Schmidt, 1984), Tn2425 yielded the structure of $\operatorname{Tn} 2424$. Deletion of a $1.45 \mathrm{~kb}$ or a $2.8 \mathrm{~kb}$ fragment from $\operatorname{Tn} 21$ resulted in the structure of $\operatorname{Tn} 2411$ or $\operatorname{Tn} 1831$, respectively. Involving the mentioned recombinational 'hot spots', the aadA gene in Tn2411 was substituted by an oxa gene to yield Tn2410 (Kratz et al., 1983a). The same sequences seem to participate in the insertion of genes into $\mathrm{Tn} 21$ as demonstrated by the structure of Tn2603 (Yamamoto et al., 1983).

This work was supported by a grant of the Deutsche Forschungsgemeinschaft to B. Wiedemann.

\section{REFERENCES}

Bachmann, B. J. (1972). Pedigrees of some mutant strains of Escherichia coli K-12. Bacteriological Reviews 36, 525-557.

BaChManN, B. J. (1983). Linkage map of Escherichia coli $\mathrm{K}-12$, edition 7. Microbiological Reviews 47, 180230.

Bennett, P. M., Grinsted, J. \& Richmond, M. H.
(1975). Transposition of $\operatorname{Tn} \mathrm{A}$ does not generate deletions. Molecular and General Genetics 154, 205 212.

Comai, L. \& Kosuge, T. (1983). Transposable element that causes mutations in a plant pathogenic Pseudomonas sp. Journal of Bacteriology 154, 11621167. 
De la Cruz, F. \& Grinsted, J. (1982). Genetic and molecular characterization of $\mathrm{Tn} 21$, a multiresistance transposon from R100.1 Journal of Bacteriology 151, 222-228.

DEAN, D. (1981). A plasmid cloning vector for the direct selection of strains carrying recombinant plasmids. Gene 15, 99-102.

DePicker, A., DE Block, M., JuzÉ, D., VAN MONTAGU, M. \& SCHELL, J. (1980). IS-element IS 8 in RP4 plasmid and its involvement in cointegration. Gene 10, $329 \cdot 338$

Galas, D. J. \& Chandler, M. (1981). On the molecular mechanism of transposition. Proceedings of the National Academy of Sciences of the United States of America 78, 4858-4862.

HaAs, M. J. \& Davies, J. (1980). Characterization of the plasmids comprising the "R-factor" $\mathrm{R} 5$ and their relationships to other R-plasmids. Plasmid 3, 260277.

Hashimoto, T. \& Sekiguchi, M. (1976). Isolation of temperature-sensitive mutants of R-plasmids by in vitro mutagenesis with hydroxylamine. Journal of Bacteriology 127, 1561-1563.

KLECKNER, N. (1981). Transposable elements in procaryotes. Annual Review of Genetics 15, 341-404.

Kratz, J., Schmidt, F. \& WiedemanN, B. (1983a). Characterization of Tn2411 and Tn2410, two transposons derived from R-plasmid R1767 and related to Tn2603 and Tn21. Journal of Bacteriology 155, $1333-1342$

Kratz, J., Schmidt, F. \& WiedemanN, B. (1983b). Transposition of a gene encoding Oxa- $2 \beta$-lactamase. Journal of General Microbiology 129, 2951-2957.

KUSHNER, S. R. (1978). An improved method for transformation of $E$. coli with ColEl derived plasmids. In International Symposium on Genetic Engineering, pp. 17-23. Edited by H. W. Boyer \& S. Nicosia. Amsterdam: Elsevier/North-Holland Biomedical Press.
Labigne-Roussel, A.\& Courvalin, P. (1983). IS15, a new insertion sequence widely spread in $\mathrm{R}$ plasmids of Gram-negative bacteria. Molecular and General Genetics 189, 102-112.

Machida, Y., Machida, C. \& OHtsubo, E. (1982). A novel type of transposon generated by insertion element IS 102 present in a pSC101 derivative. Cell 30, 29-36.

Meyer, R. J. \& Shapiro, J. A. (1980). Genetic organization of the broad-host-range IncP-I plasmid R751. Journal of Bacteriology 143, 1362-1373.

Meyer, J. F., Nies, B. A. \& WiedemanN, B. (1983). Amikacin resistance mediated by multiresistance transposon Tn2424. Journal of Bacteriology 155, 755760.

Muster, C. J. \& Shapiro, J. A. (1981). Recombination involving transposable elements: on replicon fusion. Cold Spring Harbor Symposia on Quantitative Biology 45, 93-98.

SCHMIDT, F. (1984). The role of insertions, deletions, and substitutions in the evolution of R6 related plasmids encoding aminoglycoside transferase ANT-(2"). Molecular and General Genetics 194, 248 . 259.

Tanaka, M., Yamamoto, T. \& Sawai, T. (1983). Evolution of complex resistance transposons from an ancestral mercury transposon. Journal of Bacteriology 153, 1432-1438.

Villarroel, R., Hedges, R. W, Meanhaut, R., Leemans, J., Engler, G., van Montagu, M. \& SCHELL, J. (1983). Heteroduplex analysis of P. plasmid evolution: role of insertion and deletion of transposable elements. Molecular and General Genetics 189, 390-399.

Yamamoto, T., Tanaka, M., Baba, R. \& Yamagishi, S. (1981). Physical and functional mapping of $\operatorname{Tn} 2603$, a transposon encoding ampicillin, streptomycin, sulfonamide, and mercury resistance. Molecular and General Genetics 181, 464-469. 